
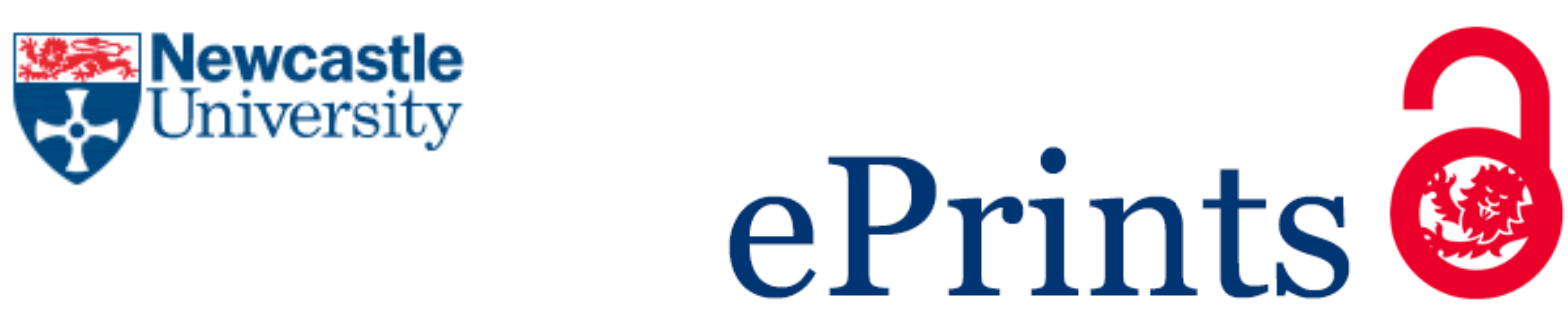

Lin X, Clay P, Hajli N, Dadgar M.

Investigating the Impacts of Organizational Factors on Employees' Unethical

Behavior within Organization in the Context of Chinese Firms.

Journal of Business Ethics 2016

DOI: http://dx.doi.org/10.1007/s10551-016-3209-4

\title{
Copyright:
}

The final publication is available at Springer via http://dx.doi.org/10.1007/s10551-016-3209-4

Date deposited:

$19 / 08 / 2016$

Embargo release date:

26 May 2017

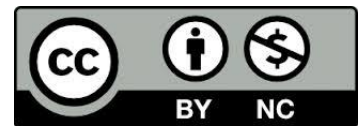

This work is licensed under a Creative Commons Attribution-NonCommercial 3.0 Unported License 


\section{Investigating the Impacts of Organizational Factors on Employees' Unethical Behavior within Organization in the Context of Chinese Firms}

Xiaolin Lin, Paul F. Clay, Nick Hajli \& Majid Dadgar

\section{Abstract}

Unethical behavior is under-examined in the workplace. To date, few studies have attempted to explore the antecedents of an employee's ethical decisions, particularly with respect to unethical behavior and its effects. To capture an employee's psychological perception of unethical behavior in the workplace, this paper integrates organizational factors (codes of conduct, likelihood of detection, and performance pressure) into the Theory of Reasoned Action. By conducting an empirical study in a Chinese firm, we found that codes of conduct and performance pressure have a significant influence on an employee's attitude toward and social beliefs about unethical behavior. We also demonstrated that employees' unethical behaviors affect the firm performance of an entrepreneurial venture. The insights gleaned from the findings on this Chinese company have a number of important implications for both research and practice.

\section{Keywords}

Codes of conducts, business ethics, unethical behavior, firm performance 


\section{Introduction}

Dishonest behaviors such as falsifying financials, overbilling, and using misleading marketing can tarnish a company's reputation, resulting in a loss of customers and revenue. Poor ethics may also reduce productivity in the workplace. (Webley and More 2003) have studied ethics and financial performance; examining three of the four measures of corporate value in their study (economic value added [EVA], market value added [MVA], and price to earnings ratio [P/E ratio]), they found that from 1997-2001, those companies in the sample with an official code of ethics outperformed a similarly sized group of companies that did not have a code. There is no doubt that codes of conduct have a significant effect on firms' financial performance.

The importance of ethics has been examined in some prior entrepreneurship studies (e.g. Morris et al. 2002, Wempe 2005, Payne and Joyner 2006). Ethical issues play an important role in the startup and development phases of new business ventures (Fassin et al. 2011). Entrepreneurial firms face challenges including financial funding, organization culture, and ethical behavior. The ethical behavior and norms within the organization impact its business performance (Verschoor 1998). However, the pursuit of organizational objectives can pit financial performance goals against the desire to 
embrace ethical business practices. Competition in the marketplace may increase unethical behavior because organizations feel the pressure to project a positive picture of their financial performance (Kaptein 2008, Grant and Visconti 2006). Therefore, it is important to understand employees' decisions regarding unethical behavior, which is critical for entrepreneurs to improve their firm performance.

Within the entrepreneurial field, some prior studies have examined ethical decisionmaking and its effects on business performance (e.g. Ackoff 1987, Morris et al. 2002). However, few studies have attempted to explore employees' psychological perceptions of unethical behavior and its effects (Chen and Tang 2006). Verschoor (1998) has demonstrated a link between overall financial performance and an emphasis on ethics as an aspect of corporate governance. He investigates whether a mainstream emphasis on corporate social and ethical accountability is consistent with superior financial performance. In his study, stakeholder accountability is the main indicator for firm performance. However, he does not discuss other elements of ethical behavior that may have influenced performance. In a more recent study, Chun et al. (2013) explored the mediators of the relationship between corporate ethics and firm financial performance. Garcia-Feijoo et al. (2005) focused in their work on the short-term and long-term performance of firms and their relationship with ethical and unethical behavior. They expand the existing literature by providing a comprehensive examination of the link between ethical behavior and firm performance using methodologies common to finance literature.

However, none of these studies have examined the influence of employees' unethical behavior on firm performance. Therefore, a deeper understanding of employees' 
perceptions regarding unethical behavior and the resulting effects on firm performance has important implications for both academics and practitioners. As such, our research question is: What are the antecedents of an employee's unethical behavior, and what are its effects?

A variety of factors ranging from personality traits of employees (e.g., Machiavellianism and extraversion) to contextual variables (e.g., industry competitiveness and presence of a code of ethics) have been investigated as possible causes of unethical conduct (Randall 1989). Some studies have also proposed frameworks and models to represent the determinants of unethical behavior (Bommer et al. 1987, Trevino 1986, Ferrell and Gresham 1985). However, the important factors that may influence employees' psychological perceptions of unethical behavior are not well captured by these studies. The tendency of people to engage in unethical behavior depends on both characteristics of the environment and characteristics of the individual (Gino and Margolis 2011). In this study, we aim to capture employees' psychological perceptions of unethical behavior by integrating intra-organization factors into the Theory of Reasoned Action (TRA). We identified three key constructs to be integrated into the TRA, thus tailoring it to capture the factors that affect employees' decisions about unethical behavior within an organization. First, researchers have demonstrated that codes of conduct play an important role in guiding employees' behavior within an organization (Weaver 1995, Trevino and Nelson 2010). Management can implement formalized codes of conduct to provide guidance to employees and monitor their behavior. Integrating codes of conduct will complement the TRA's strongest predictor: emphasizing employee attitudes toward behavior. Second, employees generally care about their performance and want better 
career development opportunities (Eisenberger and Aselage 2009). Finally, regular observation practices and annual evaluations have both become popular methods for companies to monitor their workers' behavior. Therefore, the likelihood of detection and pressure for employees to perform are integrated into our research model.

We seek to achieve two primary objectives in this study:

- Capture employees' psychological perception of unethical behavior by integrating intra-organizational factors (codes of conduct, likelihood of detection, and employees' performance pressure) into the TRA model; and

- Examine the effects of employees' unethical behavior on perceived firm performance within an entrepreneurial venture.

The remainder of this paper is organized as follows: First, we review the literature and formulate our own concise definition of unethical behavior. Second, we present a conceptual research model and develop our hypotheses. Third, the model is tested with data from an entrepreneurial firm. We conclude with a discussion of the results and implications for research and practice.

\section{Literature review}

\section{Codes of ethics and unethical behavior in business}

Although considerable research has presented ideas regarding business ethics, it is still difficult to clearly define "business ethics" as a whole. There is little agreement on what the term "business ethics" means across applications and contexts (Lewis 1985). However, it may generally be asserted that business ethics are the rules and codes that define and guide behavior within a business organization (Wood and Rimmer 2003). Business ethics, thus, are rules, standards, codes, or principles that provide guidance for morally right behavior in business decisions (Vitell and Davis 1990, Lewis 1985). 
Lewis (1985) posited two points regarding business ethics: 1) One's business ethics could not be separated from one's personal ethics; and 2) Business will never be any more ethical than the people who are in business. A business code of ethics is defined as written, distinct, formal documentation of moral standards that help guide employees and corporate behavior (Schwartz 2004). Business codes of ethics are also referred to as codes of conduct, and provide a self-regulatory standard for both employees and organizations. Thus, business codes of conducts are viewed as attempts to improve the organizational environment and to provide the basis on which behavior may be evaluated and controlled (Arrow 1973, Shaw et al. 2010). Moreover, codes of conduct are symbols of a business's commitment to ethical practices, visible to both internal and external stakeholders (Murphy 1995, Singh 2006, Singh 2011). Thus, business codes of ethics could be generally considered as prescriptions developed by a company to guide its employees' behavior (Kaptein and Schwartz 2008).

A business code of ethics is widely considered as the most frequently cited instrument to cur and preventing unethical behavior in the workplace (Kaptein and Schwartz 2008, Kaptein 2011). Business codes of ethics are used to examine ethical principles and monitor employees' behavior within a business organization. An employee's behavior may be considered either ethical or unethical according to the specific codes of ethics accepted within a given organization. Specifically, ethical behaviors are behaviors that are consistent with codes of ethics and acceptable conduct within a referent group (e.g., society, a firm, a team, or individually). On the other hand, behaviors that violate these norms are considered unethical behavior. Ethical behavior implies adherence to these moral norms, whereas unethical behavior implies the violation of these norms; unethical 
behavior involves the violation of both official standards and rules and informal social norms (Kaptein 2008). Unethical behavior within a business organization is behavior that is morally unacceptable to the larger community (Jones 1991).

Therefore, we define unethical business behavior here as those behaviors that are inconsistent with the prevailing codes of conduct and ethics within a given business organization. In this paper, we focus upon unethical behaviors within a particular type of organization: the entrepreneurial venture.

\section{Theory of Reasoned Action}

The Theory of Reasoned Action (TRA) proposed by Fishbein and Ajzen (1975) provides a general theoretical model of behavior that focuses on attitudes and social beliefs. Specifically, the TRA is based on the proposition that an individual's behavior is determined by the individual's intention to perform that behavior, which provides the most accurate prediction of behavior (Fishbein and Ajzen 1975). Attitude toward the behavior is defined as "a person's general feeling of favorableness or unfavorableness for that behavior" (Ajzen and Fishbein 1980). The TRA is concerned with consciously intended behaviors and links intention to the person's actual behavior or action. The person's attitude toward the behavior, coupled with the subjective norms concerning the behavior (i.e., assessing whether the respondent believes that others who are important to him or her think they should do X, and whether the respondent wants to comply with these beliefs) determines the behavioral intention (Kurland 1995). Attitude toward performing a given behavior is, in turn, a function of the belief that performing the behavior will lead to certain consequences and the person's evaluation of those consequences (Randall 1989). Applying the TRA to the context and research question of employee decisions on ethical behavior would suggest that an employee's unethical behavior can best be predicted by 
that individual's intention to perform the behavior, which is, in turn, determined by both that employee's attitude and subjective norms regarding ethical behavior within the organization. An employee's attitude toward ethical behavior is formed by his or her general feelings about the consequences of unethical behavior within the organization. Subjective norms are defined as an individual's perceptions of significant others' evaluation of engaging in ethical behavior within the organization. The TRA provides the primary theoretical lens for developing the research model utilized in this study. By examining attitudes, subjective norms, and behavioral intentions, businesses that wish to enhance the effectiveness of their organizations can gain an understanding of some of the barriers to effective intergroup interaction.

\section{Research model}

By incorporating intra-organization factors and employee perceptions into the TRA model, we propose an extended TRA model to enhance our understanding of an employee's unethical behavior within an organization. Starting from a pure TRA foundation, we present an overview of the constructs that are added to the TRA for this extended model. Codes of Conduct

Codes of conduct, also called codes of ethics, are defined as a written, distinct, formal documentation that consists of moral standards and which helps guide employees or corporate behavior (Schwartz 2004). In business research, such codes of conduct have been a main focus when studying business ethics. Codes of ethics are increasingly being adopted by organizations worldwide, yet their effects on employee perceptions and behavior have not been thoroughly addressed (Somers 2001). From an employee's perspective, codes of conduct provide visible guidelines for their behavior within the organization. Codes of conduct serve as a tool to improve how employees may deal with 
ethical dilemmas and to support their decision making. Many companies are trying to find ways to monitor their employees' behavior within organization by using the company's codes of conduct. Such standards of observation and detection are necessary for the organization to ensure that employees are acting consistently with the company's codes of conduct. Companies now have many strategies and processes that may be helpful in detecting and monitoring employees' behavior. Therefore, we add codes of conduct as a predictor of employee attitudes toward ethical behavior; under the TRA model, these attitudes affect employee's decisions regarding ethical behavior.

\section{Likelihood of Detection and Employee Performance Pressure}

Employees' performance is essential to organizations' success. Both regular observation and annual evaluations of employees' performance have become popular ways for management to monitor employees' work behaviors and job performance. The likelihood of detection of employees' job performance will definitely influence their psychological perceptions of ethical behavior within the organization. In addition, employees expect reward for high job performance, which increases their performance pressure (Locke and Latham 2002, Eisenberger and Aselage 2009). Such performance pressure would impact employee attitudes towards ethical behavior. Therefore, likelihood of detection and employee's performance pressure are integrated into our research model.

We have integrated these key constructs (codes of conduct, likelihood of detection, and employee performance pressure) into the TRA framework and propose an extended model that represents employees' unethical behavior in the context of an entrepreneurial venture. In addition, we also add the firm performance construct to empirically test the relationship between employees' unethical behavior and their perceptions of firm performance. Figure 1 shows our research model. 


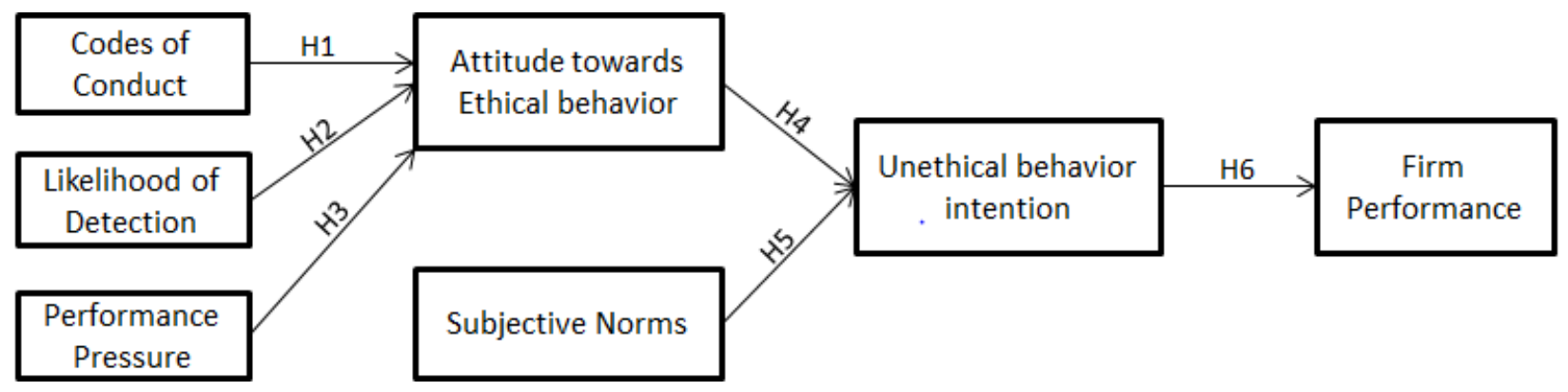

Figure 1 Research Model

\section{Hypothesis Development}

\section{Effects of Codes of Conduct on Attitude}

Codes of conduct are critical to business success. Business codes of conduct provide important guidance that is used to examine employees' behavior within organizations, and many organizations have their own codes of conduct (Benson 1989). Some prior research has reported that business codes of conduct can influence employees' behavior regarding ethical issues (Weaver 1995, Trevino and Nelson 2010). Business codes of conduct are standards and tools that are used to encourage employees to behave ethically. Corporations can be held legally responsible for the actions of their employees, and managers enact codes to guide individual behavior and to protect the corporation from any potentially illegal or unethical behavior by employees (Adams et al. 2001).

Codes of conducts are a tool for identifying specific unethical behaviors, which can lead to a reduction in unethical behavior in the workplace (Kaptein 2008). Adams et al. (2001) found that corporate codes of ethics could affect employees' ethical behavior; companies with official corporate ethics codes are more ethical in practice than those without ethics codes. In addition, a company's code informs what behavior is appropriate within the organization and warns of the consequences of unethical behavior (Trevino and Nelson 2010). 
Based on the current literature and intellectual frameworks regarding ethics in business, therefore, our hypothesis is:

$\mathrm{H} 1$ : Codes of conduct will have a positive impact on employee attitudes toward ethical behavior in entrepreneurial ventures.

\section{Effects of Likelihood of Detection on Attitude}

Job performance plays an important role for management to evaluate employees' behaviors within the organization. Employees' job performance outcomes may influence their ethical assessments and evaluations as a source of systematic bias (Selvarajan and Cloninger 2009). If employees know that they will be audited by their peers, their supervisors, and their top management teams, they are more likely to follow the company's codes of conduct and improve their job performance. Employees are more likely to obey company policies as a result of their fear of getting caught and being penalized due to the detection of job performance. Monitoring worker behavior has an effect on employees' attitudes regarding ethical behavior and, in turn, their decisions about whether to act consistently with a company's codes of conduct. We expect that the higher the likelihood of detection in a company is, the less favorably an employee will view unethical behavior. Therefore, we hypothesize:

H2: Likelihood of detection will have a positive impact on employee attitudes toward ethical behavior in entrepreneurial ventures.

\section{Effects of Performance Pressure on Attitude}

Pressure has been defined as "any factor or combination of factors that increases the importance of performing well on a particular occasion"(Baumeister 1984: p 160). Performance Pressure is pressure achieve a desired level of performance. Odiorne (1965) posited that performance pressure must be present in order to achieve the two main goals 
of organizational effectiveness: high performance and high employee satisfaction. At the individual level, performance pressure refers to the pressure that employees perceive in relation to their work activities (Zimbardo and Leippe 1991, Locke and Latham 1990, Eisenberger and Aselage 2009).

Performance pressure affects employees' attitudes; when they perceive a performance gap, they increase their commitment to overcome the gap to complete their tasks (Locke and Latham 1990, Zimbardo and Leippe 1991). This increase in commitment leads to the development of positive attitudes regarding completion of the task (Eisenberger and Aselage 2009).

Entrepreneurial firms frequently possess higher ethical attitudes than other firms because of the equity stakes and the level of risk that they face (Bucar and Hisrich 2001). The behaviors of employees are expected to be consistent with the best interest of the firm (e.g. high performance which requires the generation of value and the minimization of risk). The completion of job tasks and the attitudes toward their completion lead toward the generation of value and the minimization of risk. If an employee pursues greater value but at higher risk, they put the firm in jeopardy and thereby fail to complete their job tasks. By putting the firm in jeopardy, they act against the best interest of the firm and incongruously with the firm's ethical expectations. Therefore, when an employee faces increased performance pressure, their attitude toward ethical behavior increases because of their higher commitment to complete the tasks, which can only be accomplished if they act congruously with the firms expectations (Eisenberger and Aselage 2009, Gardner 2012).

Therefore, we hypothesize: 
H3: High performance pressure will have a positive impact on employees' attitudes toward ethical behavior in entrepreneurial ventures.

\section{Attitude toward Ethical Behavior}

Understanding an individual's rationale for ethical behavior has long been a major concern among scholars interested in business ethics (Barraquier 2011). Previous research has attempted to understand ethical decision-making in organizations through the identification of its determinants that explain why corporations are responsible and ethical (Campbell 2007). Individuals use moral reasoning and deliberation processes to adopt ethical behavior (Jones 1991, Trevino 1986). Bazerman and Banaji (2004) note that "efforts to improve ethical decision-making are better aimed at understanding our psychological tendencies" (p. 115). The tendency of people to engage in unethical behavior depends on both characteristics of the environment and characteristics of the individual (Gino and Margolis 2011). Ethical judgments, thus moderated, affect ethical or unethical behavior (Jones 1991). People want to have a positive ethical self-image and to see themselves as ethical (Aquino and Reed II 2002, Tenbrunsel 1998), but struggle to maintain this positive self-image when facing ethical or social dilemmas involving conflicts of interest. As a result, whenever their moral self-image is threatened, people are likely to behave ethically (Gino and Margolis 2011). Therefore, our hypothesis is:

H4: Attitude toward ethical behavior will be negatively related to employees' unethical intentions in entrepreneurial ventures.

\section{Subjective Norms}

Social or subjective norms not only spur but also guide action in direct and meaningful ways (Aarts and Dijksterhuis 2003, Goldstein et al. 2008). Seeking to clarify the role of social norms, Cialdini et al. (1990) and Cialdini et al. (1991) distinguished two types of 
norms. The first of these, "descriptive norms," specify what most people do in a particular situation; these norms motivate action by informing people of what is generally perceived as effective or adaptive behavior in a certain situation (Reno et al. 1993). "Injunctive norms," on the other hand, specify what people approve and disapprove of within a given culture and motivate action by promising social sanctions for counter-normative conduct. Which of these two types of norms is focal (i.e., salient) at a particular time guides an individual's immediate behavior (Cialdini et al. 1991). People adopt a new behavior based in part on their attitudes and the subjective norms promoted by influential people around them (Ajzen and Fishbein 1980, Fishbein and Ajzen 1975).

In the context of an entrepreneurial venture, top management and immediate colleagues are the influential people who shape the social norms for employees. Such peers' social norms have impacts on people's intentions of work behaviors. For example, Deng (2013) investigates the impact of subjective norms on ethical purchase intention and concludes that both group and individual social norms positively influence on consumers' ethical purchase intentions. Bobek et al. (2013) investigate the impact of social norms on tax compliance. Drawing on theory of social norms their results show that subjective norms positively influence tax compliance intentions. So, within the organizations, Subjective norms of ethical behavior within the organizations would increase employees' ethical behaviors, in other words, decreasing employees' unethical behaviors intentions. Thus, our next hypothesis is:

H5: Subjective norms of ethical behaviors will be negatively related to employees' unethical intentions in entrepreneurial ventures.

\section{Unethical Behavior and Firm Performance}


Organizations use ethics and socially responsible practices to reach their economic objectives (Barraquier 2011). Chun et al. (2013) argue that collective organizational commitment and interpersonal organizational citizenship behavior are meaningful intervening processes that connect corporate ethics to firm financial performance. Studies have examined the influence of a firm's capacity in reducing social costs (Jones 1995), the influence of social responsibility on financial performance (Barnett and Salomon 2006, De Bakker et al. 2005), the positive effect of ethical behaviors on a firm's reputation (Fombrun et al. 2000, Fombrun and Shanley 1990), and a firm's capacity to attract and retain talent (Turban and Greening 1997). Conversely, unethical behavior by employees does not seem to reap rewards (Baucus and Baucus 1997). Unethical behavior appears to gain firms little ground in terms of operating performance and stock returns, while ethical behavior improves both (Garcia-Feijoo et al. 2005). Therefore, we hypothesize: H6: Unethical behavior will have a negative impact on firm performance in entrepreneurial ventures.

\section{Research Method}

\section{Data collections}

We conducted an online survey in a construction company; the firm is an international company with primary business ventures in highway construction and real estate. The headquarters of the company are in southeast China, with several branches across China, as well as in Singapore. In total, the company has around 500 employees. We contacted the human resources director and inquired about conducting the survey within the company. We received good support and proceeded to implement the survey. The link to the online survey was first sent to the human resources director, who then transferred it to all company employees across all branches. A total of 182 responses were returned. 
Some of these were incomplete, with many missing values. We deleted those surveys, resulting in a total of 149 complete responses for a 39 percent response rate. Table 1 summarizes the respondents' demographic profile.

Table1. Demographic Information of Respondents

\begin{tabular}{|l|l|l|l|}
\hline Measure & Items & Freq. & Percent \\
\hline \multirow{4}{*}{ Gender } & Male & 88 & 59 \\
\cline { 2 - 4 } & Female & 61 & 41 \\
\hline & Below 25 & 31 & 20.8 \\
& $25-30$ & 53 & 35.6 \\
& $30-35$ & 35 & 23.5 \\
& $35-40$ & 13 & 8.7 \\
& $40-45$ & 11 & 7.4 \\
& $45+$ & 6 & 4 \\
\hline Position & Staff & 117 & 78.5 \\
& Mid-level Manager & 28 & 18.8 \\
& Top manager & 4 & 2.7 \\
\hline Work Experience (in years) & Less than 1year & 56 & 37.6 \\
& $1-2$ & 36 & 24.2 \\
& $2-3$ & 26 & 17.4 \\
& $3-4$ & 10 & 6.7 \\
& $4-5$ & 10 & 6.7 \\
& $5+$ & 11 & 7.4 \\
\hline Education & High School & 9 & 6 \\
& Associate's degree & 53 & 35.6 \\
& Bachelor's degree & 80 & 53.7 \\
& Master's degree & 7 & 4.7 \\
\hline
\end{tabular}

\section{Measurement}

Most of measurements are adapted and revised based on the prior literature using a seven-point Likert-type scale with the "strongly disagree/agree" anchors. The measurements of attitude toward ethical behavior were adapted from Fishbein (1963). The measurements of perceived likelihood of detection were revised from Bobek et al. (2007) to fit our study context. The measurements of subjective norms were adapted from Taylor and Todd (1995), who investigated the value of IT in an organization to uncover 
what determinants form such a value. The primary objective of their study is to understand whether use of IT affects productivity. In our study, we investigated the influences of codes of conduct on employees' unethical behavior, which in turn affects firm performance. The original two items were asked about whether people who influence my behavior/who are important to me would think about I should use the computing resource center (Taylor and Todd 1995). Specific to our specific research context, people who may influence my behavior (namely, act consistently with code of conduct) within the organization are top management and immediate colleagues who shape the social norms for employees in addition to their sinigifant-other. Following these studies, we modified the items accordingly to fit our research context (Bobek et al. 2013, Deng 2013).

The measurements of perceived firm performance were adapted from Wang et al. (2003). The measurements of firm pressures were revised based on Eisenberger and Aselage (2009). The measurements of codes of conduct and unethical behavior intention were developed based on prior literature. For these newly developed scales, we considered the content validity of the measures very carefully. We made several rounds of revisions to ensure that the items correctly captured the meaning of the constructs. The items of codes of conduct were developed based on its definitions from Wotruba et al. (2001) and Schwartz (2004). The measurements of unethical behavior intention were also selfdeveloped.

A pilot study was performed before we formally collected the data from our participant firm. All the survey questions were translated into Chinese by one of the study authors. Then two Chinese colleagues double-checked the translations to ensure their accuracy. We used a paper-based survey to collect data for the pilot study. A total of 62 employees 
of the company participated in the pilot study to make sure the procedure was straightforward and the scales were easy to understand. In addition, this pilot study confirmed that the scales used to measure constructs were good and the whole procedure was reasonable.

\section{Analysis and results}

\section{Analysis strategy}

The measurement model was estimated using factor analysis to test whether the constructs had sufficient validation and reliability. Then partial least squares (PLS) was used to test the structural model. PLS has been used in prior studies to measure the ethical aspect of the individuals' behavior (Buchan 2005, Fritzsche and Oz 2007). PLS has merits and advantages over other techniques, such as LISREL, for our study. We used PLS to develop and extend our research model and satisfy our exploratory experiment (Palanski et al. 2011). PLS is a good choice for behavioral and experimental research with small and large sample sizes (Buchan 2005); our model was tested with data from 149 individuals. It is also an appropriate analytical tool when the working with a relatively new research model, new constructs or when the measures employed are new (Fritzsche and Oz 2007, Sénéchal et al. 2014).

\section{Results of Measurement Model Testing}

Factor loading and average variance extracted were used to test the convergent validity and reliability of each variable in this study. We used established reliability and validity criteria to test the reliability and validity of the measurement instrument (Hair et al. 2006). All factor loadings are higher than 0.7 , which is a common rule of thumb for acceptable item loading. Table 2 provides the measurement items utilized, their means, standard deviation, factor loadings, and the Cronbach's alpha for each construct. Appendix A 
the scales of our study.

Table2. Constructs, items, mean, S.D. and factor loadings

\begin{tabular}{|c|c|c|c|c|}
\hline Constructs & Items & Mean & S.D. & Loading \\
\hline $\begin{array}{l}\text { Attitudes Toward } \\
\text { Ethical Behavior } \\
\text { (Cronbach's Alpha = } \\
\text { 0.99) }\end{array}$ & $\begin{array}{l}\text { How do you feel about acting in accordance with the } \\
\text { codes of conduct? } \\
\text { Att1 Bad - Good } \\
\text { Att2 Harmful-Beneficial } \\
\text { Att3 Foolish - Wise }\end{array}$ & $\begin{array}{l}5.63 \\
5.55 \\
5.53\end{array}$ & $\begin{array}{l}0.02 \\
0.05 \\
0.01\end{array}$ & $\begin{array}{l}0.99 \\
0.99 \\
0.98\end{array}$ \\
\hline $\begin{array}{l}\text { Perceived Codes of } \\
\text { Conduct } \\
\text { (Cronbach's Alpha = } \\
0.95 \text { ) }\end{array}$ & $\begin{array}{l}\text { Code1 My company has standards, rules and policies } \\
\text { that describe good conduct. } \\
\text { Code } 2 \text { The codes of conduct are strong in the } \\
\text { company. } \\
\text { Code } 3 \text { The codes of conduct in our company are } \\
\text { well known. } \\
\text { Code } 4 \text { Our company shares the codes of conduct } \\
\text { with employees. }\end{array}$ & $\begin{array}{l}5.26 \\
5.07 \\
5.08 \\
5.01\end{array}$ & $\begin{array}{l}0.02 \\
0.01 \\
0.02\end{array}$ & $\begin{array}{l}0.91 \\
0.93 \\
0.95 \\
0.94\end{array}$ \\
\hline $\begin{array}{l}\text { Subjective Norms } \\
\text { (Cronbach's Alpha = } \\
0.95 \text { ) }\end{array}$ & $\begin{array}{l}\text { SN1 My supervisor thinks I should act consistently } \\
\text { with our codes of conduct? } \\
\text { SN2 My colleagues think that I should act } \\
\text { consistently with our codes of conduct. } \\
\text { SN3 The top management thinks that I should act } \\
\text { consistently with our codes of conduct. } \\
\text { SN4 My significant-other thinks that I should act } \\
\text { consistently with our codes of conduct. }\end{array}$ & $\begin{array}{l}5.44 \\
5.33 \\
5.44 \\
5.17\end{array}$ & $\begin{array}{l}0.01 \\
0.02 \\
0.02 \\
0.06\end{array}$ & $\begin{array}{l}0.96 \\
0.95 \\
0.94 \\
0.88\end{array}$ \\
\hline $\begin{array}{l}\text { Firm Performance } \\
\text { (Cronbach's Alpha = } \\
0.93 \text { ) }\end{array}$ & $\begin{array}{l}\text { Perf1 My company is growing. } \\
\text { Perf2 Our company has a good competitive position. } \\
\text { Perf3 My company is successful. } \\
\text { Perf4 My company's assets are growing. }\end{array}$ & $\begin{array}{l}5.54 \\
5.23 \\
5.16 \\
5.32\end{array}$ & $\begin{array}{l}0.05 \\
0.06 \\
0.05 \\
0.05\end{array}$ & $\begin{array}{l}0.90 \\
0.91 \\
0.92 \\
0.92\end{array}$ \\
\hline $\begin{array}{l}\text { Unethical Behavior } \\
\text { Intention } \\
\text { (Cronbach's Alpha = } \\
0.87 \text { ) }\end{array}$ & $\begin{array}{l}\text { UEB1 Codes of conduct have little importance for } \\
\text { me. } \\
\text { UEB2 I would take an action that is inconsistent } \\
\text { with the firm's code of conduct if it will help me } \\
\text { achieve my goals. } \\
\text { UEB3 I would take an action that is inconsistent } \\
\text { with the firm's code of conduct if it will help my } \\
\text { firm. } \\
\text { UEB4 I would take an action that is inconsistent } \\
\text { with the firm's code of conduct if it would help my } \\
\text { supervisor. }\end{array}$ & $\begin{array}{l}2.35 \\
2.39 \\
\\
2.82 \\
2.53\end{array}$ & $\begin{array}{l}0.03 \\
0.03 \\
0.06 \\
0.07\end{array}$ & $\begin{array}{l}0.87 \\
0.88 \\
0.81 \\
0.82\end{array}$ \\
\hline $\begin{array}{l}\text { Perceived } \\
\text { Likelihood of } \\
\text { Detection } \\
\text { (Cronbach's Alpha = } \\
\text { 0.94) }\end{array}$ & $\begin{array}{l}\text { Detect1 My supervisor is likely to gauge my job } \\
\text { performance. } \\
\text { Detect } 2 \text { My department is likely to evaluate my } \\
\text { work behavior. } \\
\text { Detect3 My colleagues are likely to weigh my } \\
\text { performance. }\end{array}$ & $\begin{array}{l}5.62 \\
5.49 \\
5.48\end{array}$ & $\begin{array}{l}0.02 \\
0.03 \\
0.02\end{array}$ & $\begin{array}{l}0.90 \\
0.96 \\
0.95\end{array}$ \\
\hline $\begin{array}{l}\text { Performance } \\
\text { Pressure } \\
\text { (Cronbach's Alpha }= \\
0.86)\end{array}$ & $\begin{array}{l}\text { Ppress1 On the job, I feel I have to perform well. } \\
\text { Ppress2 I want to work harder to have better career } \\
\text { development. }\end{array}$ & $\begin{array}{l}5.86 \\
6.04\end{array}$ & $\begin{array}{l}0.03 \\
0.03\end{array}$ & $\begin{array}{l}0.92 \\
0.95\end{array}$ \\
\hline
\end{tabular}


Average variance extracted, composite reliability (CR), the root of AVE, and correlations between each pair of constructs are reported in Table 3. The AVE for each construct is above 0.5 , which indicates that the latent factors can explain at least $50 \%$ of the measured variance (Fornell and Larcker 1981). All the CRs are higher than 0.9 , which is greater than the critical value of 0.7 . To satisfy the discriminant validity, the square root of the AVE should be greater than the inter-scale correlation (Chin 1998). As shown in Table 3 , the elements along the diagonal are much greater than the off-diagonal elements. In addition, all the relationships among constructs are below the recommended value of 0.5 . The analyses confirmed convergent validity and reliability of the measurement model. Discriminant validity is also satisfied.

Table3. Correlations matrix with CR and AVE

\begin{tabular}{|c|c|c|c|c|c|c|c|c|c|}
\hline \multirow{2}{*}{ Constructs } & \multirow{2}{*}{ AVE } & \multirow{2}{*}{ CR } & \multicolumn{7}{|c|}{ Correlations } \\
\hline & & & 1 & 2 & 3 & 4 & 5 & 6 & 7 \\
\hline 1. Attitudes Toward Ethical Behavior & 0.97 & 0.99 & 0.98 & & & & & & \\
\hline 2. Perceived Codes of Conduct & 0.87 & 0.96 & 0.42 & 0.93 & & & & & \\
\hline 3. Subjective Norms & 0.87 & 0.96 & 0.27 & 0.34 & 0.93 & & & & \\
\hline 4. Firm Performance & 0.83 & 0.95 & 0.39 & 0.48 & 0.45 & 0.91 & & & \\
\hline 5. Unethical Behavior Intention & 0.71 & 0.91 & -0.29 & -0.27 & -0.29 & -0.27 & 0.84 & & \\
\hline 6. Likelihood of Detection & 0.88 & 0.96 & 0.13 & 0.16 & 0.35 & 0.49 & -0.24 & 0.94 & \\
\hline 7. Performance Pressure & 0.88 & 0.93 & 0.26 & 0.21 & 0.42 & 0.33 & -0.22 & 0.36 & 0.94 \\
\hline
\end{tabular}


To examine common method variance (CMV), we initially used Harman's single-factor test. All the variables of this study were loaded into a principal component factor analysis. The results indicated that there was not a single factor that accounted for a majority of the variance in the data set (Podsakoff et al. 2003: , p. 889). In addition to the Harman Single Factor test, we conducted a post hoc marker variable test consistent with Lindell and Whitney (2001), which provided additional support for the conclusion that the data set is not contaminated by CMV. In the post hoc test, we examined the correlation matrix of the variables. In this test, the magnitude of the lowest correlation is assumed to be the magnitude of CMV. In our data set the lowest correlation among the variables was .000 and $16.67 \%$ of all of the correlations were between -.05 and .05 . Our conclusion based upon both approaches to testing for CMV is that it is not a threat to the statistical validity of our study.

\section{Results of structural model testing}

Our structural model was tested using the partial least squares method. The results of hypothesis testing are shown in Figure 2. The $\mathrm{R}^{2}$ data account for $20.5 \%, 13 \%$, and $7.5 \%$ of the variance in attitude toward ethical behavior, unethical behavior intention, and perceived firm performance, respectively. The model is parsimonious, with only a single antecedent to the final DV Firm Performance. Table 4 also reports detailed information on the standardized path coefficients and t-values for each path of the research model. These all indicate an acceptable level of explanatory power for our research model. 


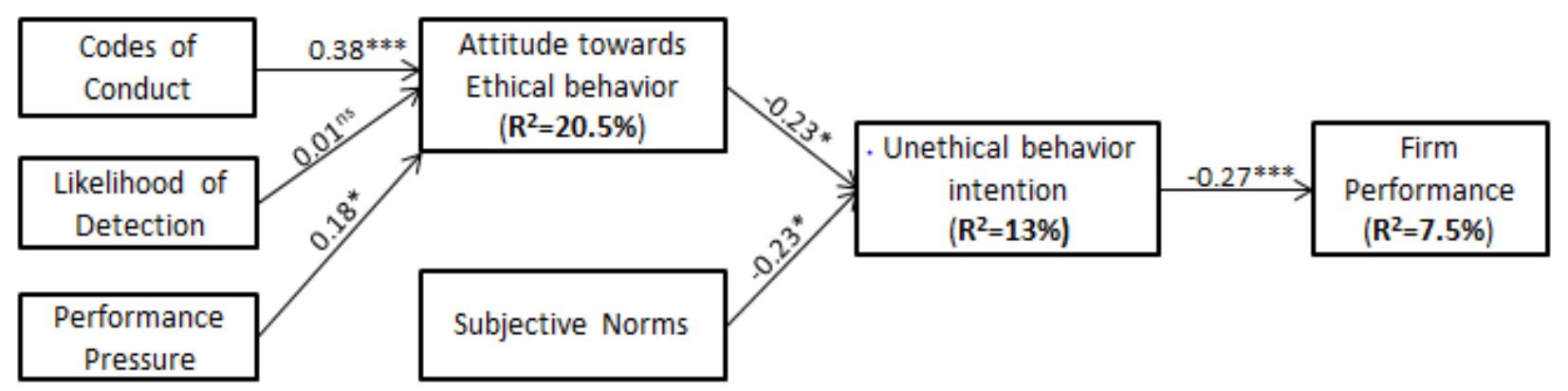

Figure 2 Results of structural model

$* 0.05$ significance; $* * 0.01$ significance; $* * * 0.001$ significance; NS = statistically not significant.

\begin{tabular}{|l|l|l|l|l|}
\hline \multicolumn{3}{|c|}{ Table 4 Path Coefficients and t-Values for the Whole Sample } \\
\hline Hypothesis & \multicolumn{1}{|c|}{ Constructs } & $\begin{array}{c}\text { Standardized } \\
\text { path } \\
\text { coefficient }\end{array}$ & $\begin{array}{c}\text { t- } \\
\text { value }\end{array}$ & $\begin{array}{c}\text { Support } \\
\text { or } \\
\text { not }\end{array}$ \\
\hline H1 & Codes of Conduct - Attitude & $0.38 * * *$ & 4.72 & YES \\
\hline H2 & Likelihood of Detection - Attitude & $0.01^{\text {ns }}$ & 0.03 & NO \\
\hline H3 & Performance Pressure - Attitude & $0.18^{*}$ & 2.11 & YES \\
\hline H4 & Attitude - Unethical Behavior Intention & $-0.23 *$ & 2.29 & YES \\
\hline H5 & Subjective norms - Unethical Behavior Intention & $-0.23 *$ & 2.48 & YES \\
\hline H6 & Unethical Behavior Intention - Firm Performance & $-0.27 * * *$ & 3.43 & YES \\
\hline$* 0.05$ significance; $* * 0.01$ significance; $* * * 0.001$ significance; NS statistically not significant. & & \\
\hline
\end{tabular}

\section{Results of hypotheses testing}

The research results support all the hypotheses except H2. An employee's attitude toward ethical behavior is shown to depend on codes of conduct and performance pressure within the entrepreneurial venture. Together with subjective norms, these attitudes and pressures affect an employee's decisions about unethical behavior decisions and also affect perceptions of firm performance. Specifically, codes of conduct and performance pressure have positive impacts on employee attitudes toward behaving ethically. Thus, $\mathrm{H} 1$ and $\mathrm{H} 3$ are supported. Furthermore, both attitude toward ethical behavior and 
subjective norms negatively influence employees' intentions to behave unethically, which in turn exerts a negative effect on employees' perceived performance pressure. These findings support $\mathrm{H} 4, \mathrm{H} 5$, and $\mathrm{H} 6$. It is worth to note that employees within the same firm may have varying perceptions of firm performance, due to individual differences of job role, training, education and experience. For instance, an employee working in inventory management may view ample stocks of inventory as a positive indicator of firm performance because they are able to readily fill orders, however a sales manager may view the same inventory levels with apprehension because they know that the firm has received fewer orders. Likewise, operations/manufacturing staff may view the fewer orders with concern while operations managers and senior managers expect lower sales of the product because they know it is being replaced with a different product design. Rarely do all employees possess complete information regarding how a firm is performing and the individual differences among employees across the firm can influence how they perceive firm performance. From this perspective, the impacts of employees' unethical behavior intentions on their perceived firm performance have interesting implementations for practice. Unfortunately, our research results suggest that $\mathrm{H} 2$ is not supported. The likelihood of detection of employees' job performance is not related to their attitude towards ethical behavior. This may indicate that employees do not fear of their supervisor's or peers' detection of their performance. They may care more about the consequences or punishments due to poor job performance. So the likelihood of detection of job performance does not affect their attitudes towards ethical behaviors, but the punishments do.

\section{Discussion}

\section{Theoretical Implications}


First, the precise definition of unethical behavior has been argued for a long time; there is a lack of clarity and consensus on the subject. Our paper offers some insights into the literature and a definition of unethical behavior that focuses on business organizations and entrepreneurship. This contributes to the literature of business ethics by providing a deeper understanding about unethical behavior from an employee's perspective. This definition highlights that the ethics of an employee's behavior depend on the codes of conduct within the organization: If an employee violates the firm's codes of conduct, his or her action is more likely to be considered unethical. This definition is useful for researchers who are interested in business ethics within an organization.

Next, this paper successfully captures an employee's psychological perception of ethical behavior, which can then be used to predict whether that employee will behave unethically. Rather than focusing on personality as in some prior studies (Randall 1989), this paper explicitly explains how organizational factors affect an employee's attitude toward ethical behavior. Codes of conduct and performance pressure have been demonstrated to be associated with an employee's attitude about business ethics. This implies that organizational factors play an important role in formulating an employee's attitude toward ethical behavior within the workplace. Placing increased institutional importance on ethical behavior reduces employees' intentions to behave unethically. This suggests additional avenues for future research that may explore more organizational factors and their effects on employees' unethical behavior.

Third, this paper confirms the importance of codes of conduct in business ventures. Therefore, it enriches the current research by incorporating codes of conduct into the study of firm performance in business ventures. Further, we have developed new 
measures for codes of conduct within an organization. This allows the analysis and measurement of aspects of business ethics and the effects of an organization's codes of conduct, and future researchers may use these measurements to conduct additional studies.

Finally, Firm Performance is a complex construct, which is at the core of management research. It is also a construct with many possible antecedents. While our parsimonious model explained $7.5 \%$ of the variance in Firm Performance with a single antecedent, a common theme across the management literature is the use of complex models employing more antecedents that explain less variance per antecedent. We encourage the adoption of parsimony as a guiding principle in formation of research models in management research.

\section{Practical Implications}

First, the research results indicate that codes of conduct can positively impact employee attitude toward ethical behavior. Business leaders must think critically about the importance of developing official codes of conduct, and about the relationship between such codes and observed employee behaviors. With an awareness of the findings of this study, management teams could build more relevant and useful codes of conduct to guide employees' behavior within an entrepreneurial venture. Additionally, the newly developed measurements for codes of ethics provide useful suggestions for management teams when formulating more efficient codes of conduct within their organizations. For example, management teams may increase the positive effects of their codes of conduct by engaging in in-depth communication about ethics with employees.

Second, the findings indicate that organizational factors have an important influence on employee behavior. Management teams need to build a good organizational environment 
and a good corporate culture. These factors have a demonstrable effect on employees' attitudes toward unethical behavior; a company culture that promotes positive social beliefs about ethical behavior will encourage its employees consistently with its codes of conducts. By implementing more efficient codes of conduct and encouraging more positive social norms, management teams could decrease employees' unethical behavior within their organizations while increasing firm performance.

Third, management teams should be aware that unethical behavior by employees will have an effect on firm performance. To improve firm performance, it is important to ensure that employees act consistently with the codes of conduct within an organization. By improving the company's codes of conduct, management teams could better guide employees' behavior in order to maximize their firm performance.

\section{Limitations and Suggestions for Future Research}

This study has some limitations. First, this study explores a limited set of antecedents of employee attitude towards ethical behavior. Future research may enrich the research model by incorporating more antecedents based on the relevant literature and theoretical perspectives for further capture employees' psychological perceptions of ethical behavior within the organization. Second, while our research model explained $7.5 \%$ of the variance in perceived firm performance, there is an opportunity to integrate our model with other factors that affect firm performance. Lastly, to generalize these findings, researchers should conduct studies in additional countries and compare the results. Cultural diversity is an important issue in business, and differences in thinking about ethical behavior in different cultures will have critical implications for global business.

\section{Conclusions}


This study extended the TRA model by integrating codes of conduct, likelihood of detection, and performance pressures as factors in studying employees' decision-making processes about unethical behavior. Codes of conduct and performance pressures have been found to significantly influence an employee's attitude toward and social beliefs about unethical behavior. The factors captured in formulating an employee's psychological perception of unethical behavior have important implications for both researchers and practitioners.

\section{Reference}

Aarts, H. \& Dijksterhuis, A. 2003. 'The silence of the library: environment, situational norm, and social behavior.' Journal of personality and social psychology, 84:1, 18.

Ackoff, R. L. 1987. 'Business ethics and the entrepreneur.' Journal of Business Venturing, 2:3, 185-91.

Adams, J. S., Tashchian, A. \& Shore, T. H. 2001. 'Codes of ethics as signals for ethical behavior.' Journal of Business Ethics, 29:3, 199-211.

Ajzen, I. \& Fishbein, M. 1980. 'Understanding attitudes and predicting social.' Behaviour. Englewood Cliffs, NJ: Prentice-Hall.

Aquino, K. \& Reed II, A. 2002. 'The self-importance of moral identity.' Journal of personality and social psychology, 83:6, 1423.

Arrow, K. J. 1973. 'Social responsibility and economic efficiency.' Public Policy, 21:3, 303-17.

Barnett, M. L. \& Salomon, R. M. 2006. 'Beyond dichotomy: The curvilinear relationship between social responsibility and financial performance.' Strategic Management Journal, 27:11, 1101-22.

Barraquier, A. 2011. 'Ethical behaviour in practice: Decision outcomes and strategic implications.' British Journal of Management, 22:s1, S28-S46.

Baucus, M. S. \& Baucus, D. A. 1997. 'Paying the piper: An empirical examination of longer-term financial consequences of illegal corporate behavior.' Academy of Management Journal, 40:1, 129-51.

Baumeister, R. F. 1984. 'Choking under pressure: self-consciousness and paradoxical effects of incentives on skillful performance.' Journal of personality and social psychology, 46:3, 610.

Bazerman, M. H. \& Banaji, M. R. 2004. 'The social psychology of ordinary ethical failures.' Social Justice Research, 17:2, 111-15.

Benson, G. C. 1989. 'Codes of ethics.' Journal of Business Ethics, 8:5, 305-19.

Bobek, D. D., Hageman, A. M. \& Kelliher, C. F. 2013. 'Analyzing the role of social norms in tax compliance behavior.' Journal of Business Ethics, 115:3, 451-68.

Bobek, D. D., Roberts, R. W. \& Sweeney, J. T. 2007. 'The social norms of tax compliance: Evidence from Australia, Singapore, and the United States.' Journal of Business Ethics, 74:1, 49-64.

Bommer, M., Gratto, C., Gravander, J. \& Tuttle, M. 1987. 'A behavioral model of ethical and unethical decision making.' Journal of Business Ethics, 6:4, 265-80.

Bucar, B. \& Hisrich, R. D. 2001. 'Ethics of business managers vs. entrepreneurs.' Journal of Developmental Entrepreneurship, 6:1, 59.

Buchan, H. F. 2005. 'Ethical decision making in the public accounting profession: An extension of Ajzen's theory of planned behavior.' Journal of Business Ethics, 61:2, 165-81. 
Campbell, J. L. 2007. 'Why would corporations behave in socially responsible ways? An institutional theory of corporate social responsibility.' Academy of management Review, 32:3, 946-67.

Chen, Y.-J. \& Tang, T. L.-P. 2006. 'Attitude toward and propensity to engage in unethical behavior: Measurement invariance across major among university students.' Journal of Business Ethics, 69:1, 77-93.

Chin, W. W. 1998. 'Commentary: Issues and opinion on structural equation modeling.' vii-xvi. MIS Quarterly.

Chun, J. S., Shin, Y., Choi, J. N. \& Kim, M. S. 2013. 'How does corporate ethics contribute to firm financial performance? The mediating role of collective organizational commitment and organizational citizenship behavior.' Journal of Management, 39:4, 853-77.

Cialdini, R. B., Kallgren, C. A. \& Reno, R. R. 1991. 'A focus theory of normative conduct: A theoretical refinement and reevaluation of the role of norms in human behavior.' Advances in experimental social psychology, 24:20, 1-243.

Cialdini, R. B., Reno, R. R. \& Kallgren, C. A. 1990. 'A focus theory of normative conduct: recycling the concept of norms to reduce littering in public places.' Journal of personality and social psychology, 58:6, 1015.

De Bakker, F. G., Groenewegen, P. \& Den Hond, F. 2005. 'A bibliometric analysis of 30 years of research and theory on corporate social responsibility and corporate social performance.' Business \& Society, 44:3, 283-317.

Deng, X. 2013. 'Factors influencing ethical purchase intentions of consumers in China.' Social Behavior and Personality: an international journal, 41:10, 1693-703.

Eisenberger, R. \& Aselage, J. 2009. 'Incremental effects of reward on experienced performance pressure: Positive outcomes for intrinsic interest and creativity.' Journal of Organizational Behavior, 30:1, 95-117.

Fassin, Y., Van Rossem, A. \& Buelens, M. 2011. 'Small-business owner-managers' perceptions of business ethics and CSR-related concepts.' Journal of Business Ethics, 98:3, 425-53.

Ferrell, O. \& Gresham, L. G. 1985. 'A contingency framework for understanding ethical decision making in marketing.' The Journal of Marketing, 87-96.

Fishbein, M. 1963. 'An investigation of the relationship between beliefs about an object and the attitude toward that object.' Human relations.

Fishbein, M. \& Ajzen, I. 1975. Belief, attitude, intention and behavior: An introduction to theory and research.

Fombrun, C. \& Shanley, M. 1990. 'What's in a name? Reputation building and corporate strategy.' Academy of Management Journal, 33:2, 233-58.

Fombrun, C. J., Gardberg, N. A. \& Barnett, M. L. 2000. 'Opportunity platforms and safety nets: Corporate citizenship and reputational risk.' Business and society review, 105:1, 85-106.

Fornell, C. \& Larcker, D. F. 1981. 'Evaluating structural equation models with unobservable variables and measurement error.' Journal of marketing research, 39-50.

Fritzsche, D. \& Oz, E. 2007. 'Personal values' influence on the ethical dimension of decision making.' Journal of Business Ethics, 75:4, 335-43.

Garcia-Feijoo, L., Jorgensen, R. \& Palanisamy, K. 2005. 'Does (un) ethical behavior affect corporate performance?' Journal of Accounting and Finance Research, 13:1, 61-76.

Gardner, H. K. 2012. 'Performance Pressure as a Double-edged Sword Enhancing Team Motivation but Undermining the Use of Team Knowledge.' Administrative Science Quarterly, 57:1, 1-46.

Gino, F. \& Margolis, J. D. 2011. 'Bringing ethics into focus: How regulatory focus and risk preferences influence (un) ethical behavior.' Organizational Behavior and Human Decision Processes, 115:2, 145-56. 
Goldstein, N. J., Cialdini, R. B. \& Griskevicius, V. 2008. 'A room with a viewpoint: Using social norms to motivate environmental conservation in hotels.' Journal of consumer Research, 35:3, 472-82.

Grant, R. M. \& Visconti, M. 2006. 'The strategic background to corporate accounting scandals.' Long Range Planning, 39:4, 361-83.

Hair, J. F., Tatham, R. L., Anderson, R. E. \& Black, W. 2006. Multivariate data analysis. Pearson Prentice Hall Upper Saddle River, NJ.

Jones, T. M. 1991. 'Ethical decision making by individuals in organizations: An issue-contingent model.' Academy of management Review, 16:2, 366-95.

Jones, T. M. 1995. 'Instrumental stakeholder theory: A synthesis of ethics and economics.' Academy of management Review, 20:2, 404-37.

Kaptein, M. 2008. 'Developing and testing a measure for the ethical culture of organizations: The corporate ethical virtues model.' Journal of Organizational Behavior, 29:7, 923-47.

Kaptein, M. 2011. 'Toward effective codes: Testing the relationship with unethical behavior.' Journal of Business Ethics, 99:2, 233-51.

Kaptein, M. \& Schwartz, M. S. 2008. 'The effectiveness of business codes: A critical examination of existing studies and the development of an integrated research model.' Journal of Business Ethics, 77:2, 111-27.

Kurland, N. B. 1995. 'Ethical Intentions and the Theories of Reasoned Action and Planned Behavior1.' Journal of Applied Social Psychology, 25:4, 297-313.

Lewis, P. V. 1985. 'Defining 'business ethics': Like nailing jello to a wall.' Journal of Business Ethics, 4:5, 377-83.

Lindell, M. K. \& Whitney, D. J. 2001. 'Accounting for common method variance in cross-sectional research designs.' Journal of applied psychology, 86:1, 114.

Locke, E. A. \& Latham, G. P. 1990. A theory of goal setting \& task performance. Prentice-Hall, Inc.

Locke, E. A. \& Latham, G. P. 2002. 'Building a practically useful theory of goal setting and task motivation: A 35-year odyssey.' American psychologist, 57:9, 705.

Morris, M. H., Schindehutte, M., Walton, J. \& Allen, J. 2002. 'The ethical context of entrepreneurship: Proposing and testing a developmental framework.' Journal of Business Ethics, 40:4, 331-61.

Murphy, P. E. 1995. 'Corporate ethics statements: Current status and future prospects.' Journal of Business Ethics, 14:9, 727-40.

Odiorne, G. S. 1965. Management by objectives: A system of managerial leadership. Pitman New York.

Palanski, M. E., Kahai, S. S. \& Yammarino, F. J. 2011. 'Team virtues and performance: An examination of transparency, behavioral integrity, and trust.' Journal of Business Ethics, 99:2, 201-16.

Payne, D. \& Joyner, B. E. 2006. 'Successful US entrepreneurs: Identifying ethical decision-making and social responsibility behaviors.' Journal of Business Ethics, 65:3, 203-17.

Podsakoff, P. M., MacKenzie, S. B., Lee, J.-Y. \& Podsakoff, N. P. 2003. 'Common method biases in behavioral research: a critical review of the literature and recommended remedies.' Journal of applied psychology, 88:5, 879.

Randall, D. M. 1989. 'Taking stock: Can the theory of reasoned action explain unethical conduct?' Journal of Business Ethics, 8:11, 873-82.

Reno, R. R., Cialdini, R. B. \& Kallgren, C. A. 1993. 'The transsituational influence of social norms.' Journal of personality and social psychology, 64:1, 104.

Schwartz, M. S. 2004. 'Effective corporate codes of ethics: Perceptions of code users.' Journal of Business Ethics, 55:4, 321-41.

Selvarajan, R. \& Cloninger, P. A. 2009. 'The influence of job performance outcomes on ethical assessments.' Personnel Review, 38:4, 398-412. 
Sénéchal, S., Georges, L. \& Pernin, J. L. 2014. 'Alliances between corporate and fair trade brands: examining the antecedents of overall evaluation of the co-branded product.' Journal of Business Ethics, 124:3, 365-81.

Shaw, W. H., Barry, V. E. \& Panagiotou, S. 2010. Moral issues in business. Wadsworth Cengage Learning Canada.

Singh, J. B. 2006. 'A comparison of the contents of the codes of ethics of Canada's largest corporations in 1992 and 2003.' Journal of Business Ethics, 64:1, 17-29.

Singh, J. B. 2011. 'Determinants of the effectiveness of corporate codes of ethics: An empirical study.' Journal of Business Ethics, 101:3, 385-95.

Somers, M. J. 2001. 'Ethical codes of conduct and organizational context: A study of the relationship between codes of conduct, employee behavior and organizational values.' Journal of Business Ethics, 30:2, 185-95.

Taylor, S. \& Todd, P. A. 1995. 'Understanding information technology usage: A test of competing models.' Information Systems Research, 6:2, 144-76.

Tenbrunsel, A. E. 1998. 'Misrepresentation and expectations of misrepresentation in an ethical dilemma: The role of incentives and temptation.' Academy of Management Journal, 41:3, 330-39.

Trevino, L. K. 1986. 'Ethical decision making in organizations: A person-situation interactionist model.' Academy of management Review, 11:3, 601-17.

Trevino, L. K. \& Nelson, K. A. 2010. Managing business ethics. John Wiley \& Sons.

Turban, D. B. \& Greening, D. W. 1997. 'Corporate social performance and organizational attractiveness to prospective employees.' Academy of Management Journal, 40:3, 658-72.

Verschoor, C. C. 1998. 'A study of the link between a corporation's financial performance and its commitment to ethics.' Journal of Business Ethics, 17:13, 1509-16.

Vitell, S. J. \& Davis, D. L. 1990. 'Ethical beliefs of MIS professionals: The frequency and opportunity for unethical behavior.' Journal of Business Ethics, 9:1, 63-70.

Wang, D., Tsui, A. S., Zhang, Y. \& Ma, L. 2003. 'Employment relationships and firm performance: Evidence from an emerging economy.' Journal of Organizational Behavior, 24:5, 511-35.

Weaver, G. R. 1995. 'Does ethics code design matter? Effects of ethics code rationales and sanctions on recipients' justice perceptions and content recall.' Journal of Business Ethics, 14:5, 367-85.

Webley, S. \& More, E. 2003. 'Does business ethics pay.' Ethics and Financial.

Wempe, J. 2005. 'Ethical entrepreneurship and fair trade.' Journal of Business Ethics, 60:3, 211-20.

Wood, G. \& Rimmer, M. 2003. 'Codes of ethics: what are they really and what should they be?' International Journal of Value-Based Management, 16:2, 181-95.

Wotruba, T. R., Chonko, L. B. \& Loe, T. W. 2001. 'The impact of ethics code familiarity on manager behavior.' Journal of Business Ethics, 33:1, 59-69.

Zimbardo, P. G. \& Leippe, M. R. 1991. The psychology of attitude change and social influence. McgrawHill Book Company. 
Appendix A Correlation among scales

\begin{tabular}{|c|rrrrrrr|}
\hline & Codes & detection & Attitude & Performance & pressure & Norms & \multicolumn{1}{l|}{ UEB } \\
\hline Code1 & $\mathbf{0 . 9 1}$ & 0.18 & 0.35 & 0.42 & 0.27 & 0.29 & -0.25 \\
Code2 & $\mathbf{0 . 9 3}$ & 0.12 & 0.40 & 0.45 & 0.19 & 0.32 & -0.21 \\
Code3 & $\mathbf{0 . 9 5}$ & 0.13 & 0.39 & 0.43 & 0.15 & 0.31 & -0.26 \\
Code4 & $\mathbf{0 . 9 4}$ & 0.18 & 0.40 & 0.48 & 0.19 & 0.34 & -0.29 \\
\hline Detect1 & 0.14 & $\mathbf{0 . 9 0}$ & 0.07 & 0.41 & 0.38 & 0.27 & -0.28 \\
Detect2 & 0.16 & $\mathbf{0 . 9 6}$ & 0.15 & 0.48 & 0.30 & 0.31 & -0.21 \\
Detect3 & 0.15 & $\mathbf{0 . 9 5}$ & 0.11 & 0.46 & 0.37 & 0.41 & -0.22 \\
\hline Att1 & 0.41 & 0.13 & $\mathbf{0 . 9 9}$ & 0.37 & 0.25 & 0.27 & -0.26 \\
Att2 & 0.41 & 0.13 & $\mathbf{0 . 9 9}$ & 0.38 & 0.24 & 0.26 & -0.29 \\
Att3 & 0.42 & 0.12 & $\mathbf{0 . 9 8}$ & 0.39 & 0.29 & 0.26 & -0.30 \\
\hline Perf1 & 0.45 & 0.53 & 0.28 & $\mathbf{0 . 9 0}$ & 0.35 & 0.42 & -0.30 \\
Perf2 & 0.43 & 0.35 & 0.41 & $\mathbf{0 . 9 1}$ & 0.25 & 0.38 & -0.22 \\
Perf3 & 0.45 & 0.40 & 0.36 & $\mathbf{0 . 9 2}$ & 0.26 & 0.43 & -0.21 \\
Perf4 & 0.40 & 0.46 & 0.38 & $\mathbf{0 . 9 2}$ & 0.33 & 0.41 & -0.24 \\
\hline Ppress1 & 0.21 & 0.36 & 0.21 & 0.25 & $\mathbf{0 . 9 2}$ & 0.43 & -0.17 \\
Ppress2 & 0.19 & 0.32 & 0.28 & 0.36 & $\mathbf{0 . 9 5}$ & 0.36 & -0.23 \\
\hline SN1 & 0.30 & 0.38 & 0.22 & 0.42 & 0.40 & $\mathbf{0 . 9 6}$ & -0.28 \\
SN2 & 0.33 & 0.33 & 0.20 & 0.43 & 0.40 & $\mathbf{0 . 9 5}$ & -0.25 \\
SN3 & 0.29 & 0.38 & 0.25 & 0.43 & 0.47 & $\mathbf{0 . 9 4}$ & -0.27 \\
SN4 & 0.36 & 0.23 & 0.31 & 0.40 & 0.30 & $\mathbf{0 . 8 8}$ & -0.27 \\
\hline UEB1 & -0.28 & -0.24 & -0.31 & -0.26 & -0.25 & -0.37 & $\mathbf{0 . 8 7}$ \\
UEB2 & -0.24 & -0.27 & -0.27 & -0.24 & -0.17 & -0.24 & $\mathbf{0 . 8 8}$ \\
UEB3 & -0.14 & -0.11 & -0.15 & -0.15 & -0.10 & -0.10 & $\mathbf{0 . 8 1}$ \\
UEB4 & -0.20 & -0.12 & -0.18 & -0.24 & -0.16 & -0.15 & $\mathbf{0 . 8 2}$ \\
\hline
\end{tabular}

